\title{
PENGARUH ETANOL, ETIL ASETAT DAN EKSTRAK ETANOL TERPURIFIKASI TERHADAP HASIL EVALUASI SIFAT FISIK SEDIAAN PATCH MUKOADHESIF EKSTRAK DAUN SIRIH (PIPER BETLE L.).
}

\author{
P. S. Yustiantara*, A. A. G. R. Yadnya-Putra, A. F. Febriana-Putra, A. A. P. Febriyana \\ Progam Studi Farmasi Fakultas Matematika dan Ilmu Pengetahuan Alam Universitas Udayana \\ *Email: putuyustiantara@yahoo.com
}

\begin{abstract}
ABSTRAK
Patch dapat mengandung lapisan polimer mukoadhesif yang berikatan dengan mukosa mulut, atau gingiva. Tanaman sirih hijau (Piper betle L.) secara empiris telah digunakan pada pengobatan gingivitis. Penelitian ini bertujuan untuk mengetahui sifat fisik dari patch yang mengandung ekstrak etanol, etil asetat, dan ekstrak etanol terpurifikasi daun sirih hijau, dilihat dari bobot matriks patch, ketebalan matriks patch, susut pengeringan matriks patch, dan ketahanan lipatan matriks patch. Ekstraksi daun sirih menggunakan metode maserasi. Patch dibuat dengan sistem matriks dengan ekstrak daun sirih dengan bahan tambahan antara lain; HPMC, PEG 400, dan mentol. Hasil uji fisik pada patch memperlihatkan bobot matrik patch ekstrak etanol $(2,153 \pm 0,077 \mathrm{~g})$, ekstrak etil asetat $(1,906 \pm 0,040 \mathrm{~g})$ dan ekstrak terpurifikasi sebesar $(1,593 \pm 0,075 \mathrm{~g})$. Tebal matrik patch ekstrak etanol $(0,61 \pm 0,613 \mathrm{~mm})$, ekstrak etil asetat $(0,57 \pm 0,576 \mathrm{~mm})$ dan ekstrak terpurifikasi sebesar $(0,55 \pm 0,550 \mathrm{~mm})$, susut pengeringan matriks patch mengandung ekstrak etanol $(4,20 \pm 4,206 \%)$, ekstrak etil asetat $(3,97 \pm 3,973 \%)$ dan ekstrak terpurifikasi sebesar $(3,67 \pm 3,673 \%)$ dan ketahanan lipatan matriks patch pada ekstrak etanol sebanyak (491 \pm 40,27 lipatan), pada ekstrak etil asetat (320 $\pm 16,65$ lipatan) dan pada ekstrak purifikasi sebesar (532 $\pm 40,55$ lipatan).
\end{abstract}

Kata Kunci: ekstrak etanol, ekstrak terpurifikasi, etil asetat, daun sirih (Piper betle L.), patch mukoadhesif,

\begin{abstract}
Patch can contain a mucoadhesive polymer layer bonded to the oral mucosa or gingiva. Green betel plants (Piper betle L.) are empirically used in the treatment of gingivitis. This study aimed to determine the physical properties of patches containing ethanol extract, ethyl acetate, and purified ethanol extract of green betel leaves, which was seen from the weight of patch matrix, patch matrix thickness, drying matrix patch, and resistance of folded matrix patch. The extraction of betel leaves was carried out using maceration method. Patches was made with a matrix system with betel leaves extract and with additional ingredients, among others; HPMC, PEG 400, and menthol. Physical test results on patch showed that the weight patch matrix of ethanol extract, ethyl acetate extract and purified extract were of $(2.153 \pm 0.077 \mathrm{~g}),(1.906 \pm 0.040 \mathrm{~g})(1.593 \pm 0.075 \mathrm{~g})$, respectively. The thick patch matrix ethanol extract, ethyl acetate extract and purified extract were of $(0.61 \pm 0.613 \mathrm{~mm}),(0.57 \pm 0.576$ $\mathrm{mm})$ and $(0.55 \pm 0.550 \mathrm{~mm})$, respectively. Drying matrix patch containing ethanol extract, ethyl acetate extract and purified extract were of $(4.20 \pm 4.206 \%),(3.97 \pm 3.973 \%)$ and $(3.67 \pm 3.673 \%)$, respectively as well as the endurance folds of patch matrix of ethanol extract patch patches, ethyl acetate extract and purification extract were of ( $491 \pm 40.27$ folds $),(320 \pm 16.65$ folds $)$ and $(532 \pm 40.55$ folds $)$, respectively.
\end{abstract}

Keywords betel leaf (Piper betle L.), ethanol extract, ethyl acetate, patch mukoadhesive, purified extract

\section{PENDAHULUAN}

Pada saat ini perkembangan sistem pengantaran obat pada bidang farmasi telah sangat berkembang, salah satunya adalah sediaan transdermal. Dimana sediaan transdermal merupakan salah satu bentuk sistem penghantaran obat dengan cara ditempel pada kulit dan memberikan efek terapeutik yang diharapkan (Barhate et al., 2009). Sediaan transdermal dapat dibuat dalam bentuk patch. Sediaan patch terdiri dari berbagai komponen yaitu liner, adhesive sebagai perekat, backing layer sebagai lapisan penahan patch, matriks sebagai pengontrol pelepasan dan plasticizer sebagai pengatur viskositas (Williams, 2004).

Patch transdermal umumnya diaplikasikan pada kulit untuk melepaskan zat aktif dalam dosis tertentu. Namun, ada juga sistem patch yang diaplikasikan dengan rute transmukosa bukal. Patch transmukosa adalah 
sistem penghantaran obat yang diletakan diantara gusi dan membran pipi bagian dalam. Kebanyakan patch transmukosa ditunjukan sebagai sediaan penghantaran obat yang bersifat sebagai anti-bakteri (Patel et al., 2009). Salah satu bakteri patogen penyebab ginggivitis adalah bakteri yang gram positif yaitu bakteri Streptococcus mutans (Manjusha et al., 2011).

Daun sirih hijau (Piper betle L.) mengandung berbagai macam kandungan kimia yaitu diantaranya : minyak atsiri, terpenoid, tanin, polifenol serta steroid. Senyawa polifenol pada ekstrak daun sirih bertanggung jawab memiliki aktivitas sebagai anti-bakteri dan anti-inflamasi (Subashkumar et al., 2013 ; Inayanti, 2010).

Menurut penelitian Sudarmadji, (1997), etanol dipilih sebagai pelarut karena etanol merupakan pelarut yang bersifat polar, Sifat yang penting adalah polaritas dan gugus polar suatu senyawa. Pada prinsipnya suatu bahan akan mudah larut dalam pelarut yang sama polaritasnya sehingga akan mempengaruhi sifat fisikokimia ekstraksi yang dihasilkan. Menurut Chakraborty dan Shah (2011), konsentrasi tanin dalam ekstrak etil asetat dari daun sirih lebih tinggi daripada dalam ekstrak etanol. Kemudian Purifikasi merupakan suatu proses menghilangkan senyawa yang tidak diinginkan. dengan metode purifikasi senyawa aktif yang diperoleh dari daun sirih lebih murni. sehingga akan meningkatkan khasiat ekstrak dan memperkecil jumlah dosis pemberian kepada pengguna (Srijanto, dkk., 2012).

Berdasarkan latar belakang yang telah dipaparkan sehingga perlu dilakukan penelitian lebih lanjut mengenai evaluasi sifat fisik sediaan patch mukoadhesif yang mengandung ekstrak etanol, etil asetat dan ekstrak terpurifikasi.

\section{MATERI DAN METODE}

\section{Bahan}

Bahan yang dipergunakan dalam penelitian ini yaitu : Etanol 96\% (teknis), Simplisia Daun Sirih Hijau ( Piper betle Linn.), yang dikumpulkan dari wilayah Desa Buduk, Kecamatan Mengwi, Kabupaten Badung, PEG 400, mentol, pharmacoat ${ }^{\circledR}$ 615, etanol, etil asetat dan Aquadest.

\section{Peralatan}

Alat yang digunakan dalam penelitian ini antara lain : Oven (Binder), Bejana Maserasi, Kain Flanel, Blender, Pengaduk Kaca, Rotary Evaporator (Stuart RE 300 DB), mesh no. 40, Lemari Pendingin, Mortir dan Stamper, Cawan Porselin, WaterBath, Set alat uji daya lekat ( Statif, Anak Timbangan, Obyek Glas). Viscosimeter (Vt-Rion 04), pH meter (Hanna ${ }^{\circledR} \mathrm{HI} 8314$ ), pengaduk magnetik (Corning $\left.{ }^{\circledR} P C-420 D\right)$ dan Timbangan analitik (Adam ${ }^{\circledR}$ AFP-360L).

\section{CARA KERJA}

\section{Ekstraksi}

Serbuk daun sirih hijau yang diperoleh dibuat menjadi tiga ekstrak dengan pelarut yang berbeda. Yang pertama, ditimbang serbuk daun sirih sebanyak 50 gram dan ditempatkan pada bejana maserasi. Kemudian dimaserasi dengan pelarut etanol $96 \%$ sebanyak $300 \mathrm{~mL}$ (ekstrak etanol $96 \%$ daun sirih). Yang kedua, ditimbang serbuk daun sirih sebanyak 50 gram dan ditempatkan pada bejana maserasi. Kemudian dimaserasi dengan pelarut etil asetat sebanyak $300 \mathrm{~mL}$ (ekstrak etil asetat daun sirih). Kemudian yang ketiga, ditimbang serbuk daun sirih sebanyak 50 gram dan ditempatkan pada bejana maserasi. Kemudian dimaserasi dengan pelarut etanol 96\% sebanyak $300 \mathrm{~mL}$ (untuk ekstrak terpurifikasi daun sirih). Kemudian dilakukan pengadukan dan ketiga bejana maserasi ditutup rapat dan didiamkan selama 24 jam pada suhu kamar $\left(28^{\circ}-32^{\circ} \mathrm{C}\right)$ terlindung dari cahaya. Hasil maserasi disaring untuk dipisahkan antara ampas dan filtratnya. Ampas dimaserasi kembali dengan pelarut yang sama yaitu etanol 96\% dan etil asetat masing masing sebanyak $300 \mathrm{~mL}$, dilakukan dua kali pengulangan. Setelah pengulangan dua kali, semua hasil maserat yang diperoleh diuapkan pelarutnya dengan bantuan alat rotary evaporator, pemanas water bath dengan suhu $70^{\circ} \mathrm{C}-80^{\circ} \mathrm{C}$, kemudian dikeringkan dalam oven pada suhu $45^{\circ} \mathrm{C}$ hingga diperoleh ekstrak kental (Arifin dkk, 2009).

Selanjutnya dilakukan purifikasi untuk ekstrak terpurifikasi. Ekstrak kental etanol daun sirih hijau (Piper betle L.) dilarutkan dengan etanol $96 \%$, kemudian dimasukan ke dalam corong pisah $100 \mathrm{~mL}$. Ditambahkan pelarut etil asetat dengan perbandingan 1:2 v/v. Kemudian dilakukan penggojogan dan didiamkan hingga terbentuk 2 fase yaitu fase 
atas yang merupakan fase etil asetat dan fase bawah yaitu fase etanol air kedua fase ditampung terpisah, fase bawah diekstraksi kembali dengan menggunakan etil asetat dengan akuades, hingga terbentuk dua fase. Kedua fase ditampung secara terpisah. Proses ini dilakukan berulang hingga terbentuk fase etil asetat yang jernih. Fase etanol air yang diperoleh kemudian disebut dengan ekstrak terpurifikasi. Ekstrak terpurifikasi diuapkan pelarutnya dengan bantuan alat rotary evaporator, pemanas water bath dengan suhu $70^{\circ} \mathrm{C}-80^{\circ} \mathrm{C}$, kemudian dikeringkan dalam oven pada suhu $45^{\circ} \mathrm{C}$ hingga diperoleh ekstrak purifikasi kental (Widyaningtyas, 2014).

\section{Skrining Fitokimia}

\section{a) Uji Alkaloid}

Serbuk simplisia dibasakan dengan amonia, kemudian ditambahkan kloroform, digerus kuat-kuat. Lapisan kloroform dipipet sambil disaring, kemudian ke dalamnya ditambahkan asam klorida 2 N. Campuran dikocok kuat-kuat hingga terdapat dua lapisan. Lapisan asam dipipet, kemudian dibagi menjadi 3 bagian. Bagian 1 ditambahkan pereaksi Mayer. Bila terjadi kekeruhan atau endapan berwarna putih berarti di dalam simplisia kemungkinan terkandung alkaloid. Bagian 2 ditambahkan pereaksi Dragendorff. Bila terjadi kekeruhan atau endapan berwarna jingga kuning berarti dalam simplisia kemungkinan terkandung alkaloid. Bagian 3 digunakan sebagai blangko (Depkes RI, 1989).

\section{b) Uji Saponin}

Sejumlah kecil serbuk simplisia dalam tabung reaksi dipanaskan dalam penangas air kemudian disaring. Setelah dingin filtrat dalam tabung reaksi dikocok kuat-kuat selama kurang lebih 30 detik. Pembentukan busa sekurangkurangnya setinggi $1 \mathrm{~cm}$ dan persisten selama beberapa menit serta tidak hilang pada penambahan satu tetes asam klorida encer menunjukkan bahwa dalam simplisia terdapat saponin (Depkes RI, 1989).

\section{c) Uji Fenol}

Sejumlah kecil serbuk simplisia dalam tabung reaksi dipanaskan dalam penangas air, kemudian disaring. Ditambahkan larutan pereaksi $\mathrm{FeCl}_{3}$ kedalam filtrat. Terbentuknya senyawa fenolat ditandai dengan terjadinya warna hijau-biru hingga hitam (Depkes RI, 1989).

\section{Pembuatan Patch Mukoadhesif \\ Menurut literatur diperoleh} perbandingan proporsi komposisi PEG 400 dan Mentol adalah $(0,637: 1,363)$ (Padmanaba, 2016). Patch dibuat menggunakan sistem matriks. HPMC dimasukkan kedalam gelas beker, kemudian tambahkan mentol sesuai jumlah dalam masing-masing formula, kemudian masukkan PEG 400 ke dalam gelas beker sesuai jumlah dalam masing-masing formula, ditambahkan $5 \mathrm{~mL}$ ekstrak daun sirih kedalam gelas beker, Masing-masing formula dibuat $17 \mathrm{~mL}$. kemudian diaduk dengan magnetic stirrer dengan kecepatan $1150 \mathrm{rpm}$ selama 30 menit. Campuran yang homogen dituang ke dalam cawan petri dengan diameter dalam lingkaran $6 \mathrm{~cm}$ dan dibiarkan mengering dalam oven suhu dengan $45^{\circ} \mathrm{C}$ sampai mencapai bobot matriks yang diinginkan. Matriks yang sudah kering dipotong sirkuler dengan diameter $2,95 \mathrm{~cm}$, dibungkus dengan aluminium foil, disimpan dalam desikator sebelum pengujian.

\section{Evaluasi Fisik Matriks Patch}

\section{a) Uji Bobot Matriks Patch}

Pengujian variasi bobot patch pada tiap formula dilakukan dengan cara menimbang satu persatu patch. Penimbangan dilakukan replikasi 3 kali pada patch yang berbeda dari formula yang sama, kemudian dihitung bobot rataratanya (Parivesh dkk., 2010).

b) Uji Ketebalan Matriks Patch

Ketebalan patch diukur dalam titik yang berbeda dengan menggunakan jangka sorong dan menentukan ketebalan rata-rata dan standar deviasi yang sama untuk memastikan ketebalan patch (Pariveshet al., 2010). Ukuran ketebalan patch bukal sebaiknya antara 0,5-1,0 $\mathrm{mm}$, apabila lebih kecil akan menyulitkan dalam pemakaiannya. Jika terlalu tebal membuat pemakaian tidak nyaman, jika terlalu tipis akan menyulitkan pemakaian (Mathiowitz et al., 199).

\section{c) Persentase Susut Pengeringan Matriks Patch.}

Matriks ditimbang satu persatu dan dimasukan ke dalam desikator selama 24 jam, kemudian matriks kembali ditimbang satu persatu setelah penyimpanan dalam desikator tersebut. Setelah itu dihitung selisih bobot matriks sebelum dan sesudah dimasukan ke dalam desikator. Hasil perhitungan tersebut 
dinyatakan sebagai angka persentase susut pengeringan. Susut pengeringan berperan dalam menjaga kestabilan fisik patch, sebab presentase susut pengeringan yang kecil akan membuat fisik matriks patch tetap lentur dan tidak rapuh sehingga patch masih nyaman saat digunakan (Parisvesh et al., 2010).

\section{d) Uji Ketahanan Lipatan Matriks Patch}

Uji ketahanan suatu patch dilakukan dengan cara dilipat berulang kali di tempat yang sama sampai pecah. Banyaknya lipatan yang dapat dilakukan dianggap sebagai nilai ketahanan (Parisvesh et al., 2010). Ketahan lipatan patch yang baik berada pada kisaran lebih dari 250 lipatan (Baviskar dan Jain, 2009).

\section{HASIL DAN PEMBAHASAN}

\section{Ekstraksi}

Pada penelitian ini, proses ekstraksi dengan menggunakan metode maserasi diperoleh ekstrak kental etanol $96 \%$ sejumlah 4,86 gram dari 50 gram serbuk daun sirih dan rendemen ekstrak yang diperoleh sebesar 9,72\%. Kemudian ekstrak kental etil asetat diperoleh sejumlah 3,50 gram dari 50 gram serbuk daun sirih dan rendemen ekstrak yang diperoleh sebesar 7\%. Pada ekstrak terpurifikasi diperoleh ekstrak kental sejumlah 3,80 gram dari 50 gram serbuk daun sirih dan rendemen ekstrak yang diperoleh sebesar $7,6 \%$. Hal ini menunjukkan bahwa, dari ketiga ekstrak yang dibuat sudah memenuhi persyaratan Farmakope Herbal Indonesia dengan total rendemen ekstrak daun sirih yaitu lebih dari 5\% (Farmakope Herbal Indonesia, 2010).

\section{Skrining Fitokimia}

Hasil skrining fitokimia daun sirih menunjukan bahwa mengandung Alkaloid dan fenol. Ini membuktikan daun sirih mengandung senyawa aktif metabolit sekunder. Pada pengujian alkaloid menunjukan hasil positif pada ekstrak etil asetat dan ekstrak purifikasi dengan menggunakan pereaksi Mayer terdapat endapan putih, dengan pereaksi Wagner terjadi perubahan warna coklat kemerahan, sedangkan pada ekstrak etanol tidak terdapat endapan putih pada uji Mayer. Diperkirakan endapan putih tersebut adalah kompleks kalium-alkaloid. Pada pembuatan pereaksi mayer. Larutan merkurium (II) klorida ditambah kalium iodide akan bereaksi membentuk endapan merah merkurium(II) iodide. Jika kalium iodida yang ditambahkan berlebihan maka akan membentuk kalium tertraiodomerkurat (II). Alkaloid mengandung atom nitrogen yang mempunyai pasangan elektron bebas sehingga dapat digunakan untuk membentuk ikatan kovalen dengan ion logam. Pada uji alkaloid dengan pereaksi Mayer, diperkirakan nitrogen pada alkaloid akan bereaksi dengan ion logam $\mathrm{K}+$ dari kalium tertraiodomerkurat (II) membentuk kompleks kalium-alkaloid yang mengendap.

Hasil positif pada uji Wagner ditandai dengan terbentuknya endapan coklat kemerahan. Diperkirakan endapan tersebut adalah kalium-alkaloid. Pada pembuatan pereaksi wagner, iodine bereaksi dengan ion Idari kalium iodide menghasilkan ion 13- yang berwarna coklat. Pada uji Wagner, ion logam k+ akan membentuk ikatan kovalen dengan nitrogen pada alkaloid akan membentuk kompleks kalium-alkaloid yang mengendap.

Pada uji saponin hasil negatif ditunjukan dengan tidak adanya busa yang terbentuk. karena tidak adanya busa pada saat penambahan pereaksi Air + HCl. Dikarenakan tidak adanya glikosida yang mempunyai kemampuan membentuk buih dalam air yang terhidrolisis menjadi glukosa dan senyawa lainnya.

Hasil uji fenol menunjukan ketiga ekstrak tersebut bereaksi positif dengan $\mathrm{FeCl} 3$. Ini menunjukan bahwa ketiga ekstrak tersebut mengandung senyawa fenol. Senyawa fenol bereaksi dengan $\mathrm{FeCl} 3$. Akan menghasilkan senyawa kompleks fenol dan Fe3+ yang berwarna hijau-biru hingga hitam..Senyawa fenol dengan gugus hidroksil yang semakin banyak memiliki tingkat kelarutan dalam pelarut polar yang lebih besar. 
Pengaruh Etanol, Etil Asetat dan Ekstrak Etanol Terpurifikasi Terhadap Hasil Evaluasi Sifat Fisik Sediaan Patch Mukoadhesif Ekstrak Daun Sirih (Piper Betle L.)

(P. S. Yustiantara, A. A. G. R. Yadnya-Putra, A. F. Febriana-Putra, A. A. P. Febriyana)

Tabel 1. Hasil Uji Skrining Fitokimia Ekstrak Daun Sirih (Piper betle L.)

\begin{tabular}{|c|c|c|c|}
\hline \multirow{2}{*}{ Ekstrak } & \multicolumn{3}{|c|}{ Skrining Fitokimia } \\
\hline & Uji Alkaloid & Uji Saponin & Uji Fenol \\
\hline Etanol 96\% & $\begin{array}{l}\text { Reagen Mayer: Tidak terdapat } \\
\text { endapan putih (-). } \\
\text { Reagen Wagner: Terdapat } \\
\text { endapan coklat kemerahan }(+) \text {. }\end{array}$ & $\begin{array}{c}\text { Tidak terbentuk } \\
\text { busa }\end{array}$ & $\begin{array}{c}\text { Terjadinya warna hijau- } \\
\text { biru hingga hitam }(+)\end{array}$ \\
\hline Etil Asetat & $\begin{array}{lr}\text { Reagen Mayer: } & \text { Terdapat } \\
\text { endapan putih }(+) . & \\
\text { Reagen Wagner: } & \text { Terdapat } \\
\text { endapan coklat kemerahan }(+) .\end{array}$ & $\begin{array}{c}\text { Tidak terbentuk } \\
\text { busa }\end{array}$ & $\begin{array}{c}\text { Terjadinya warna hijau- } \\
\text { biru hingga hitam }(+)\end{array}$ \\
\hline Terpurifikasi & $\begin{array}{lr}\text { Reagen Mayer: } & \text { Terdapat } \\
\text { endapan putih (-). } & \\
\text { Reagen Wagner: } & \text { Terdapat } \\
\text { endapan coklat kemerahan }(+) .\end{array}$ & $\begin{array}{c}\text { Tidak terbentuk } \\
\text { busa }\end{array}$ & $\begin{array}{c}\text { Terjadinya warna hijau- } \\
\text { biru hingga hitam }(+)\end{array}$ \\
\hline
\end{tabular}

Tabel 2. Hasil Evaluasi Fisik Matriks Patch (Piper betle L.)

Evaluasi Fisik Matriks Patch (rata-rata \pm SD)

\begin{tabular}{ccccc}
\cline { 2 - 5 } Ekstrak & $\begin{array}{c}\text { Uji Bobot } \\
\text { Matriks Patch } \\
\text { (gram) }\end{array}$ & $\begin{array}{c}\text { Uji Ketebalan } \\
\text { Matriks Patch } \\
05-1,0(\mathrm{~mm})\end{array}$ & $\begin{array}{c}\text { Persentase Susut } \\
\text { Pengeringan Matriks } \\
\text { Patch }(-10 \%)\end{array}$ & $\begin{array}{c}\text { Uji Ketahanan } \\
\text { Lipatan Matriks } \\
\text { Patch (300 lipatan) }\end{array}$ \\
\hline Etanol 96\% & $2,153 \pm 0,077$ & $0,61 \pm 0,613$ & $4,20 \pm 4,206$ & $491 \pm 40,27$ \\
Etil Asetat & $1,906 \pm 0,040$ & $0,57 \pm 0,576$ & $3,97 \pm 3,973$ & $320 \pm 16,65$ \\
& & & & \\
Terpurifikasi & $1,593 \pm 0,075$ & $0,55 \pm 0,550$ & $3,67 \pm 3,673$ & $532 \pm 40,55$ \\
& & & & \\
\hline
\end{tabular}

\section{Evaluasi Fisik Matriks Patch Mukoadhesif 1. Bobot Matriks Patch.}

Bobot matriks patch paling besar dihasilkan oleh ekstrak etanol sebesar 2,153 \pm 0,077 gram, sedangkan bobot matriks patch terkecil dihasilkan oleh ekstrak terpurifikasi sebesar 1,593 $\pm 0,075$ gram. Pengujian bobot matriks patch pada masing-masing ekstrak dilakukan dengan cara menimbang satu persatu matriks patch, kemudian dihitung ratarata bobot dari masing-masing variasi.

Hasil pengujian bobot matriks patch pada masing-masing ekstrak menghasilkan bobot matriks patch yang bervariasi, yakni yang terbesar adalah patch yang mengandung ekstrak etanol $(2,153 \pm 0,077 \mathrm{~g})$, kemudian ekstrak etil asetat $(1,906 \pm 0,040 \mathrm{~g})$ dan terkecil adalah patch yang mengandung ekstrak terpurifikasi sebesar $(1,593 \pm 0,075 \mathrm{~g})$.

Perbedaan bobot patch yang dihasilkan disebabkan karena adanya perbedaan campuran ekstrak dalam matriks patch yang dibuat. Perbedaan kandungan jenis ekstrak tersebut akan mempengaruhi permeabilitas dari matriks patch. Penggunaan ekstrak yang terpurifikasi diduga mengurangi kemampuan dari polimer untuk mengikat air. Hal tersebut menyebabkan bobot matriks patch akan berkurang juga. Selain itu adanya proses purifikasi akan menghilangkan senyawa yang tidak diinginkan seperti zat warna (pigmen), tannin, karbohidrat, lilin, resin juga ikut 
terektraksi pada proses sebelumnya. Keberadaan senyawa atau zat tersebut lebih banyak merugikan dari pada kestabilan dan mengurangi kadar senyawa aktif di dalam ekstrak (Srijanto,dkk., 2012).

\section{Tebal Matriks Patch.}

Hasil pengujian ketebalan matriks patch pada masing-masing ekstrak diukur dengan menggunakan jangka sorong digital dengan tingkat ketelitian $0,01 \mathrm{~mm}$. Pengukuran tebal matrik patch dilakukan dengan cara mengukur tebal matriks patch pada tiga 3 titik yang berbeda dari masing-masing matriks patch. Ketiga ekstrak menghasilkan tebal matriks patch yang bervariasi. Ketebalan matriks patch paling besar dihasilkan oleh patch yang mengandung ekstrak etanol $(0,61 \pm 0,613 \mathrm{~mm}$ ) , kemudian ekstrak etil asetat $(0,57 \pm 0,576$ $\mathrm{mm})$ dan terkecil adalah patch yang mengandung ekstrak terpurifikasi sebesar $(0,55 \pm 0,550 \mathrm{~mm})$.

Hasil pengukuran tebal matriks patch ini berkaitan dengan pengukuran pada bobot matriks patch dimana seiring dengan menurunnya bobot matriks patch pada setiap ekstrak, terjadi juga penurunan pada ketebalan dari matriks patch. Kenyamanan penggunaan patch mukoadhesif dipengaruhi oleh karakter fisik matriks patch tersebut, salah satunya adalah ketebalan matriks patch. Semakin tipis matriks patch yang dihasilkan akan menyebabkan semakin nyaman patch tersebut digunakan. Ukuran ketipisan patch mukoadhesif antara 0,5-1,0 mm (Mathiowitz et al., 199), apabila ketebalannya kurang akan menyulitkan proses pemakaiannya. Hasil penelitian menunjukan bahwa patch yang mengandung ekstrak terpurifikasi berada pada rentang patch yang baik, yaitu 0,5-1,0 mm. Jika patch melewati rentang batas patch terbaik akan mengganggu aktivitas dan memberikan tampilan patch yang kurang baik secara estetika.

Pengujian susut pengeringan dilakukan dengan memasukkan matriks patch ke dalam desikator selama 24 jam, kemudian matriks patch dikeluarkan dari desikator. Selanjutnya dihitung selisih bobot matriks patch sebelum dimasukkan ke dalam desikator dan sesudah dimasukkan ke dalam desikator, hasil perhitungannya dinyatakan sebagai angka susut pengeringan.

\section{Susut Pengeringan Matriks Patch.}

Hasil yang didapat dari susut pengeringan matriks patch mukoadhesif cukup bervariasi. Susut pengeringan paling besar dihasilkan oleh patch yang mengandung ekstrak etanol $(4,20 \pm 4,206 \%)$, kemudian ekstrak etil asetat $(3,97 \pm 3,973 \%)$ dan terkecil adalah patch yang mengandung ekstrak terpurifikasi sebesar $(3,67 \pm 3,673 \%)$. air yang masih tersisa dalam ekstrak pada kadar lebih dari $10 \%$ dapat menjadi media pertumbuhan mikroba. selain itu, dengan adanya air, akan terjadi reaksi enzimatis yang dapat menguraikan zat aktif sehingga mengakibatkan penurunan mutu atau perusakan ekstrak. Hasil perhitungan susut pengeringan ekstrak menunjukkan bahwa dalam ekstrak terpurifikasi daun sirih tidak terlalu banyak kandungan senyawa yang menguap, yaitu dengan rata-rata susut pengeringan 3,67 \%. Hal ini mengindikasikan bahwa dalam ekstrak terpurifikasi daun sirih hanya sedikit terkandung air.

Susut pengeringan berperan dalam menjaga kestabilan fisik patch, sebab presentase susut pengeringan yang kecil akan membuat fisik matriks patch tetap lentur dan tidak rapuh sehingga patch masih nyaman saat digunakan. Jumlah susut pengeringan yang rendah juga akan membuat patch lama bertahan melekat pada mukosa, sehingga zat aktif dapat dilepaskan secara perlahan.

\section{Ketahanan Lipatan Matriks Patch}

Hasil pengujian ketahanan lipatan pada ketiga ekstrak tidak menunjukkan perbedaan yang signifikan satu sama lain. Hasil uji memperlihatkan bahwa ketiga ekstrak tersebut memiliki tingkat ketahanan lipatan yang sama yakni lebih dari 300 lipatan. Pada ekstrak etanol sebanyak (491 $\pm 40,27$ lipatan), pada ekstrak etil asetat $(320 \pm 16,65$ lipatan $)$ dan pada ekstrak purifikasi sebesar (532 $\pm 40,55$ lipatan).

Salah satu faktor yang mempengaruhi daya lipat suatu patch yaitu adanya pemakaian polietilen glikol 400 sebagai plasticizer. Polietilen glikol mampu meningkatkan elastisitas patch melalui berbagai macam mekanisme diantaranya, peningkatan permeabilitas dari patch dengan meningkatkan pembasahan patch sehingga patch menjadi lebih hidrofilik dan menurunkan kristalinitas polimer sehingga patch lebih elastis dan lentur (Suprioto, 2010). 


\section{SIMPULAN DAN SARAN}

\section{Simpulan}

Dari keempat parameter uji fisik matriks patch yang dilakukan pada patch mengandung ekstrak etanol, ekstrak etil asetat dan ekstrak etanol terpurifikasi. diperoleh patch yang mengandung ekstrak etanol terpurifikasi memiliki sifat fisik yang paling baik. Yaitu dengan bobot $(1,593 \pm 0,075 \mathrm{~g})$, ketebalan $0,55 \pm 0,550 \mathrm{~mm}(0,5-1,0 \mathrm{~mm})$ dan susut pengeringan $3,67 \pm 3,673 \%(-10 \%)$ serta daya lipatan sebanyak $532 \pm 40,55$ lipatan (300 lipatan).

\section{Saran}

Perlu dilakukan uji aktifitas anti bakteri terhadap Streptococcus mutans secara invitro, serta perlu dilakukan penentuan formula optimal dari ekstrak etil asetat dan ekstrak terpurifikasi.

\section{UCAPAN TERIMAKASIH}

Penulis mengucapkan terimakasih kepada pegawai Laboratorium Farmasetika Dasar dan Laboratorium Fitokimia atas bantuan fasilitas penelitian.

\section{DAFTAR PUSTAKA}

Agarwal, Tarum., Rachana, Singh., Amar, Deep Shukla., Imran, Waris and Ankita, Gujrati, 2012, Comparative analysis of antibacterial activityof four Piper betle varieties, Amity University :Pelagia Research Library.

Arifin, M.F, Liliek N. Syarmalina dan Rensy, 2009, Formulasi Edible Film Ekstrak Daun Sirih (Piper betleL.) Sebagai Aniholitosis, Kongres Ilmiah ISFI XVII.

Chakraborty, D and Shah, B., 2011, Antimicrobial, antioxidative and antihemolytic activity of piper betle leaf extracts. Int. J. Pharm. Sci., 3 (3): 192199.

Depkes RI., 1989,Materia Medika Indonesia Jilid V,Jakarta :Departemen Kesehatan Republik Indonesia.

Depkes RI, 2000, Parameter Standar Umum Ekstrak Tumbuhan Obat. Jakarta

Gandjar, I, G. dan A. Rohman, 2007, Kimia
Farmasi Analisis,Yogyakarta :Pustaka Pelajar.

Jawetz, Melnick, and Adelberg, s., 2004, Mikrobiologi Kedokteran, Ed 23, Penerbit Buku Kedokteran EGC, Jakarta page 233,235.

Kumar, V, Aggarwal, G, Zakir F dan Choudhary, A., 2011, Buccal Bioadhesive Drug Delivery- A Novel Technique, International Journal of Pharmacy and Biological Sciences, 1 (3): 89-102.

Mathiowitz, E., 1999, Controlled Drug Delivery (Vol. $1 \&$ 2), New York: John Wiley \& Sons, Inc., 65-68.

Manjusha, S. and Sarita,G.B., 2011, Plasmid associated antibiotic resistance in Vibrios isolated from coastal waters of Kerala. International Food Research Journal.18: 1171- 1181.

Padmanaba, P., 2016, Pengaruh PEG 400 dan Menthol Terhadap Pelepasan Senyawa Polifenol Secara In-Vitro Dari Matriks Patch Mukoadhesif Ekstrak Etanol Daun Sirih (Piper betleL) Berbahan Pharmacoat ${ }^{\circledR}$ 615:Skripsi, Jimbaran: Jurusan Farmasi Pakultas Matematika Dan Ilmu Pengetahuan Alam Universitas Udayana.

Parisvesh, S., Sumeet, D., and Abhishek, D., 2010, Design, Evaluation, Parameters and Marketed Products of Transdermal Patches, J. Pharm. Res 3(2): 235-240.

Patel, D.P., Setty, C.M., Mistry., G.N., Patel , L.S., Patel, T.J., Mistry, P.C., Rana, A.K., Patel, P.K., dan Mishra, R.S., 2009, Development and Evaluation of Ethyl Cellulose-Based Transdermal Films of Furosemide for Improved In Vitro Skin Permeation, Pharm. Sci. Tech., 10 (2): 437-442.

Widyaningttias, N. M. S. R., 2014, Uji Aktivitas Antibakteri Ekstrak Terpurifikasi Daun Sirih Hijau (piperbetlle L.) Terhadap Bakteri Propioni bakterium acnes, Skripsi. Jurusan : Farmasi Universitas Udayana.

Williams, A., 2004, Transdermal and Topical Drug Delivery: From Theory to Clinical Practice, London: Pharmaceutical Press. 120-125. 